AFRICAN

\title{
Forum: Security and engagement: the case of China and South Sudan
}

\author{
by Ross Anthony* \\ Centre for Chinese Studies, University of Stellenbosch \\ Stellenbosch, South Africa \\ and Jiang Hengkun ** \\ Institute of African Studies, Zhejiang Normal University \\ Jinhua, China
}

\begin{abstract}
As Chinese engagement in Africa grows, questions surrounding its role in security have become more prominent. The issue of security is a broad one ranging from China's role in regional security with international organisations to the role of securing assets and personnel. This forum piece addresses some of these concerns, with a particular focus on South Sudan. While the Chinese state has been relatively adept at establishing ties with Africa's newest country, due to China's previous close relationship with the Khartoum regime (an enemy of the South), friction has persisted. This is particularly evident at the level of everyday Chinese-South Sudanese engagement, which is fraught with security risks. The piece describes some of these issues by drawing on fieldwork observations and interviews conducted in April 2013, eight months before the country lapsed back into civil war.
\end{abstract}

*Ross Anthony is the Interim Director of the Centre for Chinese Studies at the University of Stellenbosch in Stellenbosch, South Africa.

**Jiang Hengkun is a Faculty Member at the Institute of African Studies at Zhejiang Normal University, China. 
AFFAIRS

\section{Introduction}

China's engagement with Sudan can be situated within China's broader 'go global' drive which has sought to strengthen diplomatic ties with countries possessing resources crucial to its national strategy imperatives (Large 2008; Taylor 2006). Since 1993, China has become a net importer of oil; with its shift toward a market economy, China's manufacturing, development projects and growing consumption have driven the country to secure energy supplies abroad. Its oil companies increasingly operate like those of other developed states, seeking to secure supplies vital to their respective economies. Throughout Africa, Chinese National Oil Companies (NOCs) compete and co-operate with other multi-nationals; while China is the dominant partner in Sudan and South Sudan, there are a host of other actors, many of which are also from Asia ${ }^{1}$.

In fulfilling this quest for energy security, China has been obliged to commercially engage in some of the most insecure regions in the world. China's resource search has led it to engage in a number of 'frontier' oil resource regions in Africa, including The Democratic Republic of Congo (DRC), Somalia and Ethiopia. China's interest in such regions has been driven, at least in part, by the fact that various former colonial powers, as well as the United States of America, had already carved out significant oil enclaves for themselves within sub-Saharan Africa (Yates 2012:13-14) ${ }^{2}$. Only beginning oil production in the 1990s, China has been a late-comer. While establishing oil ties with countries (such as Nigeria and Angola) already involved with western partners, China additionally sought partnerships with states either deemed high-risk or having poor relations with the western world. Sudan was one such state: not only did it have a tumultuous relationship with western powers ${ }^{3}$ but also faced several major insurgencies within its own borders.

A major security challenge which Chinese companies have faced has been the split of Sudan into two countries, with the formal founding of the Government of South Sudan (GoSS) in July 2011. China's infrastructure, which had initially been developed on the basis of a single, unified Sudan, now faced the problem of existing 


\section{AFRICAN \\ EAST-ASIAN \\ AFFAIRS

between two sovereign states. The oil fields which straddle the border of the two countries are where significant Chinese development is located. For instance, the state-owned China National Petroleum Corporation's (CNPC) holds concessions in both the Heglig and Unity oil fields - fragile border regions in the Mugald basin. This oil is then transported over Sudanese territory to the Red Sea in Port Sudan, via the Chinese constructed and operated $1600 \mathrm{~km}$ Greater Nile Oil Pipeline (GNOP). As part of the agreement of the split between the two Sudans, the South received roughly 75 per cent of the existing oil fields. Thus, it was crucial for China to establish good relations with the new government so as to secure its investments.

This enterprise has gone hand in hand with targeted and sustained diplomacy. China's engagement with South Sudan at the level of state has been remarkably pragmatic. Beijing supported the Comprehensive Peace Agreement (CPA) which marked the end of the second Sudanese civil war (1983-2005) and which set a timetable for a referendum for South Sudanese independence (Large 2012:11). Additionally, in terms of greater regional security, Beijing contributed Chinese United Nations peacekeeping troops to the Darfur region in 2008. Following independence on July 9, 2011, then Chinese president Hu Jintao sent an envoy to sign a joint communiqué with Southern officials; the new state was recognised, diplomatic relations were established and China upgraded its consulate in Juba into an embassy (International Crises Group 2012: 4). Foreign Minister Yang Jiechi soon visited, announcing plans for future engagement in energy, infrastructure, telecommunications, and agriculture; there was also the gifting of the construction of two secondary schools, a 500 bed hospital, a 'friendship hall' and a national theatre. Additionally, the two governments agreed to maintain the terms of existing oil contracts (Ibid). The South's heavy reliance on oil for its economy coupled with the fact that China already had invested heavily in oil infrastructure made China an attractive partner. Juba insisted that CNPC establish offices in Juba; they initially established a small office in the capital and are presently in the process of building much larger premises.

While China is a dominant player in oil extraction in Sudan and South Sudan, it is 
AFFAIRS

not oil alone upon which the relationship exists. Other industries investing in the country have strengthened China's economic diplomacy with the South. China is in the process of developing South Sudan's mining sector and considering a loan of between US\$ 1billion and US\$ 2 billion for road, power and agriculture projects (Green, 2013). Chinese Telecommunication giant ZTE, with the backing of China's Exim Bank, is in the process of constructing a 51 million dollar digital communication system (Embassy of South Sudan, 2013). Zhong Hao Construction Company has supplied water and sanitation facilities, government housing, a teaching hospital, roads and a series of multi-purpose buildings; Sinohydro has provided a water plant in Western Equatroia, a thirty seven kilometre road in Malakal and high-way construction linking the North and the South. (International Crises Group 2012: 20). Additionally, the number of Chinese in Juba has grown significantly, including small-traders, shop-owners, and other service industry entrepreneurs. China has also sponsored business trips to China for the South Sudanese business community (Xinhua News, 2013).

China views its particular model of economic engagement within South Sudan and Africa more generally - as an ultimately stabilising force which will contribute toward greater peace and stability. A government White Paper on the relationship forwards the principles of "Safeguarding peace, promoting development and enhancing cooperation" (People's Daily 2006). The developmental aspect of China's view toward peace is significant, primarily because such a model has contributed toward such massive poverty alleviation within China itself. The Chinese proverb often cited, "to get rich, build a road first" encapsulates a view in which the state enables the population to economically enable themselves. Within Africa, China's extractive industry deals often come in a package form, in which Chinese companies will include the construction of dams, bridges and roads as part of their engagement (Brautigram, 2010; Alves, 2012). In war-torn regions such as Angola, the DRC and Sudan, these infrastructure projects are urgently needed, where they enable citizens to be more productive. Such relationships are complimented by a general increase in trade activity. Coupled with this the Chinese adherence to the non-interference principle, in which China professes not to meddle in the political 


\section{AFRICAN \\ EAST-ASIAN \\ AFFAIRS

affairs of South Sudan and other countries. Thus, China officially views this engagement as a 'win-win' situation, in which both countries stand to benefit. As economic development increases in South Sudan ${ }^{4}$, so, according to this view, do the prospects of peace and security.

\section{Engagement on the ground}

At the level of state engagement, the relationship between South Sudan and China has been relatively successful. It has strengthened its relations with GoSS, secured its pre-existing assets and brokered numerous infrastructure deals. However, at the level of daily engagement between Chinese company's and citizens, security remains a major concern. As the Chinese presence has grown on the African continent, so has exposure to political risk. Within Africa as a whole, there have been incidents in which Chinese citizens have faced significant danger. For instance, in 2006, the Nigerian group MEND threatened to attack Chinese workers and their infrastructure projects in retaliation to growing Chinese oil investments in the country (Obi, 2010: 422). In April 2007, nine Chinese and sixty five Ethiopian oil engineers were killed by the Ogaden Liberation Front (ONLF) while prospecting for oil in eastern Ethiopia. China has also faced hostility in Zambia's copper mining region, leading to riots and several deaths; Zambian presidential candidate, Michael Sata, campaigned for the Zambian presidency using anti-Chinese rhetoric (although this was toned down since winning the presidency) $)^{5}$.

Despite the good relations between GoSS and the PRC, significant security risks remain for Chinese citizens and companies. There are still significant regions of the country over which the government does not exert control. Certain oil rich regions, such as Abeyi, are claimed by the South and held by the North. Neighbouring territories, such as South Kordofan's Heglig region, where the Chinese have oil investments, have been subject to instability. In April 2012, the region was captured by the South Sudanese army for a period of ten days. In January 2012, the South closed all wells in a spat over pipeline fees, which lasted until March 2013. In interviews with CNPC officials, they spoke of how SPLA soldiers, with very little warning, forced them to hastily shut down their operations, damaging expensive equipment in 
AFFAIRS

the process (Interview, March, 2013). Since re-opening, there have been further threats of oil shutdown. In 2012, twenty-nine Chinese citizens working for Sinohydro on the construction of a highway were abducted by the Sudan People's Liberation Army (North) [SPLA(N)]. GoSS officials have also intervened in the running of corporate affairs. For instance, in 2012, Liu Yingchai, head of Petrodar, was expelled from South Sudan, on grounds of "non-cooperation" (Sunday Tribune, 2013). Following the relapse into civil war at the end of 2013, the situation has deteriorated significantly, with CNPC evacuating staff from many of the oil blocks within which it operates.

Political instability, coupled with the crucial role of oil in the South Sudanese economy, has entailed that the security of oil installations has remained largely in the hands of the SPLA (Sudan People's Liberation Army). In 2013, the SPLA covered the costs of the military presence; a central security department was set up to liaise between the oil companies and the military. Relations between the companies and the military were generally good, although friction arose occasionally over issues of soldiers pay. In order to prevent corrupt relations between soldiers and local communities, soldiers from other regions of South Sudan were frequently brought in to protect installations. This did, however, increase potential for friction between the soldiers and the local communities. While it is common for host African states to offer security to Chinese companies engaging in the resource sector, the GoSS tended to view this measure as temporary. The ideal behind the process was that once there was sufficient stability within the region, the GoSS intended to hand over the role of protecting the oil industry to private security and military firms (Interview, March, 2013). While the SPLA protects the parameters of the production centres, the various companies which constitute a consortium such as the Greater Nile Petroleum Company (GNPOC), of which CNPC is a part, has used private security companies within the compound for further protection. While central processing facilities have protected by the army, various individual wells are not, and are occasionally sabotaged by local communities.

Within the non-oil sector, there also existed numerous risks. In many respects, 


\section{AFRICAN \\ EAST-ASIAN \\ AFFAIRS

Chinese workers face the same general problems as other foreigners working in the region. Water supply issues, malaria and access to fresh food are common problems. From a commercial point of view, there are also issues of procurement difficulties, slow administrative processing and corruption. Due to general crime within the city of Juba, most foreigners live and work in compounds. These are shut off from the surrounding city with high walls and armed security services. At present there are no Chinese private security companies operating in South Sudan. This is reflective of Africa in general, where such a presence is minimal ${ }^{6}$. Only one private security company in South Sudan, Veteran Security Services (VSS), comprised largely of former SPLA regiments, has the legal right to hold arms. Other companies are compelled to contact the police if force is needed. Thus, despite certain arguments suggesting that private security firms challenge and even undermine the sovereign authority of particularly weak states (Verkuil, 2007) in South Sudan, the state is intimately linked to the security companies.

Within recent years, Beijing has itself become more active in securing its citizens abroad. A major turning point in China's commitment to protecting its citizens abroad came during the Libyan civil war of 2011, when China evacuated over 35000 Chinese citizens. President Hu Jintao issued a statement urging government workers "to spare no efforts to ensure the safety of life and properties of Chinese citizens in Libya" (Embassy of PRC in the US 2011) ${ }^{7}$. Pressure to protect Chinese citizens abroad has also become a domestic priority; on Chinese internet chatforums such as Weibo. During the South Kordofan kidnapping incident in South Sudan in 2011, Chinese 'netizens' complained about the Chinese state's inability to intervene; some even called for PLA troops to be sent into Sudan to rectify the situation (Weibo 2013). In April 2010, with the Sudanese national elections approaching, the Consulate General in Juba urged overseas-funded enterprises to improve security awareness, with exchanges of relevant information between both the consulate and business and sustained close contact between the two parties (Xia 2013: 93). More generally, Chinese embassies abroad are increasingly trying to improve leasing with citizens. In countries such as South Africa and Botswana for instance, Chinese voluntary task forces have been set up which liaise with local police to help 
AFFAIRS

prevent crimes against Chinese citizens (Ibid, 94).

Chinese embassies are active through the Chinese internet messaging system, QQ, which alerts citizens to various dangers. Within Juba, Chinese information sharing and its circulation in Juba is distinct from other parts of the foreign community. The embassy does its intelligence gathering on security via the government but also through Chinese companies which have their own close links to the government. While there is a communal circulation of security updates amongst the foreign community (via various companies, embassies and the United Nations Department of Safety and Security) the Chinese tend to have their own intelligence lines which are distinct from other parties of the foreign community. The large state and private companies receive reports in advance by the government and vice versa. Despite such implementation, there is still much scope for the role of embassies in the protection of Chinese citizens. Chinese commercial actors still lack a clear and formalised system which can contribute to their security (Steineke 2013: 22). Additionally, those who work as traders or in small enterprises tend to have a less intimate relationship with the embassy ${ }^{8}$. Some traders interviewed stated that they had virtually no contact with the embassy at all.

\section{Engagement as a security measure}

While there is a perception in some quarters that Chinese citizens in South Sudan have been specifically targeted because their presence is not wanted, this is tempered when we consider the nature of Chinese labour itself. Unlike many other foreign entities working in South Sudan, Chinese companies are often involved in construction in the South Sudanese hinterland, of which many parts remain politically volatile. Additionally, the Chinese bring in large pools of labour from China - usually from China's large migrant class of peasants - to assist in the construction. They shoulder the bulk of the risk as they often work in harsh conditions in the most insecure regions. In certain instances, where Chinese have been kidnapped, they have been engaged in projects with government support but located in regions where the state does not exert full control ${ }^{9}$. Thus, the nature of Chinese labour, coupled with the fact that it is carried out in sometimes highly unstable 


\section{AFRICAN \\ EAST-ASIAN \\ AFFAIRS

political contexts, exacerbates the risk which Chinese citizens face.

Nevertheless, the particular historical trajectory between China and Sudan has entailed a comparatively unique situation in which South Sudanese tend to express a pronounced animosity toward the Chinese presence. Because of China's adherence to the "Mutual respect for each other's territorial integrity and sovereignty", as part of its Five Principles of Peaceful Coexistence, its support for Khartoum entailed a tacit resistance to the separatism in break-away regions such South Sudan and Darfur. China's sale of weapons to the al-Bashir regime and producer of huge oil windfalls to his regime were also contributing factors. Additionally highly visible public campaign waged by western NGO's, such as China's 'Genocide Olympics', lent international credence to their grievances more generally. This historical relationship persisted particularly within the oil sector. CNPC's 1999 development of Northern Unity Province's Block 1, was marred by forced land clearances through violent means. Sudanese Government forces, as well as armed militias backed by the al-Bashir government, launched several attacks on the ethnic Dinka, burning food, houses and seeds and driving them from their land (Human Rights Watch 2013: 125-126) . These events were part of a much broader process of violent land clearance, including other multi-nationals such as Sweden's Lundin and Austria's OMV, who were involved in even more severe forms of land clearance in Block 5a. As a consequence, the reputation of China suffered in the eyes of many South Sudanese.

Exacerbating such grievances is the fact that oil industry engagement has, through hyper securitisation, failed to adequately engage with the political and economic contexts in which they are embedded. A recurrent grievance expressed by such communities has been the lack of direct and sustained contact between Chinese representatives and local communities. Several government officials interviewed stated that Chinese companies generally prefer GoSS officials to act as a liaison between themselves and the local communities. Local communities have their own forms of organisation. For instance, communities in the oil regions of Jonglei, Upper Nile and Unity State have set up what are termed "Oil Task Forces". The local County 
Commissioner helps organise the taskforce, which ideally consists of about seven members of local communities, including local chiefs, elders (retired government officials) women and youth. The community meetings aim to encourage dialogue among the government, the local communities and the oil companies. However, Chinese oil companies have been slow in reciprocating. One informant interviewed stated that when attempting to approach the public relations offices of CNPC with queries, he was instructed that he should approach the government with his problems, rather than the company.

More generally, a sentiment was expressed amongst the Chinese community that they were being singled out for negative treatment by South Sudanese, because they were Chinese. In certain cases, the Chinese workers in the service sector interpreted the likes of random fines, detainment and extortion as a deliberate targeting. The working relationship between the two communities was exacerbated various other forms of cultural difference. The language barrier (English speaking South Sudanese could not communicate with the Chinese), entailed that interaction between officials and local Chinese was fraught with misunderstanding, frequently ending in the Chinese side paying a fine to resolve a given issue. Chinese work teams expressed reluctance to hire South Sudanese labourers as their work ethic was not considered on par with Chinese expectations; the South Sudanese often quarrelled over money, sometimes threatening violence; if the authorities were brought in to settle a dispute, interviewees claimed that such officials often sided with the aggrieved South Sudanese party. Chinese firms thus preferred to hire more labourers from neighbouring countries such as Uganda and Ethiopia as they are considered to be better disciplined labourers.

Within China, with its authoritarian system and ubiquitous state presence, large companies can engage in projects with little hindrance or protest. Abroad, China has faced greater criticism of its investments and is increasingly integrating a Corporate Social Responsibility (CSR) into their business models abroad. In a shift from its earlier engagement, CNPC has within recent years striven to pay greater attention to Corporate Social Responsibility (CSR) within the Sudanese region ${ }^{10}$. 


\section{AFRICAN \\ EAST-ASIAN \\ AFFAIRS

For instance, the company has sponsored South Sudanese students to attend the Chinese University of Petroleum in Beijing and has donated US\$ 700,000 for a computer laboratory to the University of Juba. According to company representative; the proportion of local employees working on oil projects for CNPC globally exceeds 95 per cent (Jiang and Heng 2013: 22). In addition, CNPC developed medical facilities, contributed US\$ 1.6 million toward a sewage treatment plant, and assisted in the reconstruction of Juba's airport. CNPC's branding has shifted, with its new Logo 'Caring for Energy, Caring for You'.

Nevertheless, there remains much to be done with regards to community engagement. As Zhang and Jiang state in their work on community in engagement in South Sudan, 'it is an essential ingredient in obtaining local legitimacy and preventing local populations from feeling marginalised' (Ibid). In this sense, we understand the concept of security not just in securing personnel and assets but also contributing toward a greater secure environment. Such engagement also offers Chinese actors greater insight into the kinds of effects they are having on communities and the possibility of mitigating those effects which are negative. The notion of community engagement fits in with China's wider aims of providing security in Africa through investment.

\section{Engagement and the non-interference principle}

A broader issue which has the potential to exacerbate security concerns is China's policy of non-interference, insofar as it can be perceived as insensitive to local context. Within Sudan, this is particularly complicated, not only because Sudan's sovereignty was split into two but also because China was uniquely politically aligned to the Khartoum regime (Large, 2008). Daniel Large has noted with regard to China's engagement with Sudan, that principle of sovereignty as exerting full control over a territory is not suitable to the context (Large, 2012:612). This is reflective of the broader African context in which states, often recent colonial contractions, govern over encompassing wide ranges of religious and ethno-linguistic differences; weak central governance often compounds the issue of exerting sovereign control. The colonial construction of the British designated Sudan is a good example of this, with 
AFFAIRS

Arab-dominated Khartoum struggling to maintain hegemony over vast swathes of the South (present-day South Sudan) and the West (Darfur). Although China was able to reconfigure relations with the new government of South Sudan relatively successfully, the tensions between Chinese and South Sudanese touched on above, indicates a collateral effect of this policy.

Additionally, China's non-interference principle suggests that there is a sharp distinction between political engagement and economic engagement. The principle of the policy emerged during the Cold War period and was implemented as a response to what the Chinese government viewed as imperial encroachment by the United States of America on China's neighbours ${ }^{11}$. Since then, one of its functions has been to highlight that, unlike the Euro-American sphere, China does not intervene in the affairs of other states. In September 2014 China announced that it would deploy 700 soldiers under the auspices of the United Nations primarily to protect civilian workers in South Sudan (Bloomberg 2014). The move differs from a similar decision to deploy Chinese troops to Mali in 2013 insofar as this latter situation did not involve Chinese oil interests. While media reports quickly pointed out that China was now actively violating its 'non-interference principle', the United Nations Mission for South Sudan quickly dismissed this accusation (Reuters 2014).

More broadly, the non-interference principle fails to address is how economic engagement itself is often inextricably bound up with politics itself. The issue of the 'non-interference' policy as inadequate for China's engagement in the $21^{\text {st }}$ century has not gone unnoticed within China. The political scientist Wang Yizhou, has forwarded the concept of "creative involvement", which envisions a more active China, attaching greater importance to global and regional public goods; such goods not only forward the "friendship" aspect of China's foreign policy but also function as strategic strengthening of China's co-operation mechanisms (2013)

The oil industry, in general, offers a prime example of this. In terms of oil development within the world's least developed states, there is strong evidence that engagement - by China or any other foreign company - leads to an increase in 


\section{AFRICAN \\ EAST-ASIAN \\ AFFAIRS

political and social problems. Michael Ross, in analysing 170 countries and drawing on 50 years of data, concludes that, within the developing world, oil states are, amongst other things, for instance, "twice as likely to have civil wars as the non-oil states" as well as being more secretive, more financially volatile, and more discriminatory towards women (2012:1-2). While it is not inevitable that hydro-carbon development in the developing world will contribute to social and political malaise (Dunn, 2008; Di John, 2011), it is a very significant possibility. In the case of Sudan, the war between the North and the South had been in existence prior to the development of oil. Nevertheless, oil exacerbated the stakes in the war, allowed alBashir's National Congress Party with its petro-dollars, to continue waging war. It also tore communities apart when the establishment of the oil production centres entailed mass forced migration by government proxy militias.

But the exertion of political effects upon local politics are often not so dramatic. For instance, in oil producing states where increased revenues ideally create conditions for increased community prosperity but in reality create political rivalry for access to these revenues. High levels of corruption and the entrenchment of patronage politics entails that contending for state level jobs in such provinces can lead to conflict. This is evident in Unity State, where Governor Taban Deng, who has ruled since 2005, has been accused of favouring certain ethnic groups as well as vote rigging. Subsequently, several armed rebellions have broken out, some of which have targeted Chinese nationals (because discouraging Chinese oil investments directly affects the governor's access to revenue).

\section{Conclusion}

As China continues to engage in Africa, it will need to increasingly develop a new policy language which can better articulate its relationship and thus ensure the longterm security of both Chinese citizens but also those south Sudanese citizens amongst whom they work. China is a relatively late player in Africa and has confronted a steep learning curve. As its presence continues within South Sudan, but also in Africa at large, China will need to increasingly engage with local communities and develop policies which promote such engagement. This will offer a more 
AFRICAN

EAST-ASIAN

AFFAIRS

THE CHINA MONITOR

secure environment, thus benefiting both parties.

\section{Endnotes}

${ }^{1}$ Within Sudan, China extracts oil as part of the multi-national consortium called the Greater Nile Petroleum Operating Company (GNPOC), which includes Malaysia's Petronas, Sudan's Sudapet and India's Oil and Natural Gas Corporation. CNPC holds a 40 per cent stake in the company. Other prominent international companies include Total and Exxon Mobil.

${ }^{2}$ The British have traditionally exerted a heavy influence in Nigeria, as the French have in regions such as Gabon and Equatorial Guinea. The United States of America have had a heavy presence in regions such as Angola, where the former colonial power, Portugal, did not have sufficient means to develop the industry.

${ }^{3}$ The June 1989 coup by the NIF (National Islamic Front) saw Sudan become a haven for various Islamic political groups, including Osama Bin Laden form 1991 to 1996. Sudan also supported Iraq during the Persian Gulf War and had links with the 1993 World Trade Centre bombings, leading the USA to put Sudan on a list of countries which sponsored terrorism; UN sanctions were also imposed (Patey, 2007: 1004)

${ }^{4}$ When Xi Jinping met David Deng Athorbei, envoy of the South Sudanese government, in 2011, he stated: "China is ready to promote its friendly exchanges with southern Sudan on the basis of the Five Principles of Peaceful Coexistence," A keystone of these five principles is that of 'non-interference'. See 'China expresses willingness to boost cooperation with Southern Sudan, promises further aid' (Peoples Republic of China Embassy in South Sudan 2013).

${ }^{5}$ For more examples on the dangers Chinese citizens have faced in Africa, see Holslag (2009).

${ }^{6}$ This situation looks set to change. There are over 4000 private security compa- 


\section{AFRICAN \\ EAST-ASIAN \\ AFFAIRS

nies in China, with many eager to expand their market share overseas (Grimm \& Anthony, 2013).

${ }^{7}$ The evacuation involved the People's Liberation Army Navy (PLAN), the Ministries of Foreign Affairs, Commerce, Public Security, the Civil Aviation Administration and various consular officials as well as co-ordination with large SOEs including CNPC and China Rail Construction; Consulates in Malta and Greece as well as an airbase in the Sudan were also mobilised. The PLAN sent a 4000 ton missile frigate to evacuate citizens and four military transport aircraft were also sent (Anthony \& Grimm, 2013).

${ }^{8}$ For comparative accounts of poor relations between Chinese citizens and their embassies, see Janssen, 2010; Krahl \& Su, 2013.

${ }^{9}$ This can be seen, for instance, in the South Kordofan kidnapping mentioned. The construction of the road was under the auspices of the Khartoum government. However, the road led into territory controlled by the rebel Sudan People's Liberation Movement-North (SPLM-N), where the Chinese were detained, the SPLM-N claims, for their own safety.

${ }^{10}$ Within China, there have been significant policy shifts regarding Chinese companies investing abroad, including the 2006 'Corporation Law' providing a legal foundation for CSR and the 'Guidelines for CSR compliance for Foreign-Invested Enterprises' issued in 2008 by the Chinese Academy of International Trade and Economic Cooperation.

${ }^{11}$ The principle was originally forged by Premier Zhou Enlai and Indian Prime Minister, Jawaharlal Nehru to reduce border tensions and improve Sino-Indian relations (Haas and Aidoo 2010: 325).

\section{Bibliography}

Alves, Ana Christina. 2012. China’s ‘Win-Win' Cooperation: Unpacking the Impact 
AFFAIRS

of Infrastructure-for-Resources Deals in Africa. South African Journal of International Affairs, 20 (2): 207-226.

Bloomberg. 2014. China to deploy troops to protect South Sudan oil facilities [Online]. Available: http://www.bloomberg.com/news/2014-09-10/china-to -deploy-troops-to-protect-south-sudan-oil-installations.html [2013, December 12].

Brautigram, Deborah. 2010. The Dragon's Gift: The Real Story of China in Africa. Oxon: Oxford University Press.

Di John, Jonathan. 2011. Is There Really a Resource Curse? A Critical Survey of Theory and Evidence. Global Governance, 17: 167-184.

Dunning, Thad. 2008. Crude Democracy: Natural Resource Wealth and Political Regimes. Cambridge: University of Cambridge Press.

Embassy of the Republic of South Sudan, ZTE to Up-grade South Sudan Telecommunications System [Online]. Available: http:// southsudanembassybeijing.com/information-detail.aspx?i=12_[November $12]$.

Green, Andrew. 2013. China to Help South Sudan Develop Mining Sector and Infrastructure. Business Day, 10 September 2013.

Grimm, Sven \& Anthony, Ross. 2013. Chinese Engagement in African Security Pragmatism and Shifts under the Surface. Centre for Chinese Studies, Policy Brief.

Heng, Jiang \& Zhang, Hui. 2013. Managing Security Challenges for Chinese Companies in South Sudan. Oil, Security and Community Engagement: A Collection of Essays on China's Growing Role in South Sudan, London: Saferworld: 21-24.

Hess, Steve \& Aidoo, Richard. 2010. Beyond the Rhetoric: Non-interference in China's African Policy. African and Asian Studies, 9: 356-383. 
AFRICAN

EAST-ASIAN

AFFAIRS

Holslag, Jonathan. 2009. China's New Security Strategy for Africa. Parameters, 39 (2): 23-3.

International Crises Group, 2012. China's New Courtship in South Sudan, Africa Report, 186:1-39.

Janssen, Johanna. 2010. DRC: Chinese Investment in Katanga. Pambazuka News. [Online]. Available: http://www.pambazuka.org/en/category/ africa_china/63573 [17 July].

Krahl, Danila \& Su, Jinxia. 2013. The Latest Victims of the Euro Crisis - Chinese Grocers in Africa. Centre Commentary. Centre for Chinese Studies, 5 September. [Online]. Available: http://www.ccs.org.za/wp-content/ uploads/2013/10/CCS_5_September_Daniel_Commentary_Africa_Edits.pdf [19 November 2013].

Large, Daniel. 2012. Between the CPA and Southern Independence: China's Postconflict Engagement in Sudan. South African Institute for International Affairs, Occasional Paper, 15: 1-28.

Large, Daniel, 2009. China's Sudan Engagement: Changing Northern and Southern Political Trajectories in Peace and War. The China Quarterly, 199: 610-626.

Large, Daniel. 2008. Sudan's Foreign Relations with Asia: China and the Politics of "Looking East". Institute of Security Studies, Paper, 158: 1-20.

Large, Daniel. 2008. China and the Contradictions of "Non-interference" in Sudan. Review of African Political Economy, 35 (115): 93-106.

Obi, Cril. 2010. Enter the Dragon? Chinese Oil Companies and Resistance in the Niger Delta. Review of African Political Economy, 35 (3): 417-434.

Patey, Luke. 2007. State Rules: Oil Companies and Armed Conflict in Sudan. Third World Quarterly, 28(5): 997-1016, 1004.

China's African Policy. People's Daily, 12 January 2006. [Online]. Available: http://en.people.cn/200601/12/eng20060112_234894.html [7 September 
AFRICAN

EAST-ASIAN

AFFAIRS

2013].

Peoples Republic of China Embassy in South Sudan. [Online]. Available: http:// ss.chineseembassy.org/eng/sbgx/thybt/t850826.htm [9 October 2013].

2014. UN Says China Not Yet Deploying Peacekeepers in South Sudan. Reuters, 10 September. [Online]. Available: http://www.trust.org/ item/20140910084628-kth0k/ [12 December].

Ross, Michael L. 2012. The Oil Curse: How Petroleum Wealth Shapes the Development of Nations, Princeton: Princeton University Press.

Steineke, Tim. 2013. Chinese Engagement in South Sudan and the Management of Insecurity and Conflict. Oil, Security and Community Engagement: A Collection of Essays on China's Growing Role in South Sudan, London: Saferworld: 21-24.

2013. Head of Petrodar Oil Company Expelled from South Sudan. Sudan Tribune. [Online]. Available: http://www.sudantribune.com/spip.php?article41676 [12 September 2013].

Taylor, Ian. 2006. China's Oil Diplomacy in Africa. International Affairs, 82(5): 937-959.

Verkuil, Paul. 2007. Outsourcing Sovereignty: Why Privatization of Government Functions Threatens Democracy and What We Can Do About It. Cambridge: Cambridge University Press.

Wang, Yizhou. 2013. Creative Involvement: The Evolution of China's Global Role, Beijing: Peking University Press.

Xia, Liping. 2013. An Analysis of China's Consular Protection Practice in Africa. African-East Asian Affairs, 3: 83-106.

South Sudan Delegation Attends Trade Fair in China. Xinhua News, October 19 2013. [Online]. Available: http://news.xinhuanet.com/english/china/2013 -10/19/c_132812424.htm [9 November 2013]. 


\begin{tabular}{|c|l}
\hline AFRICAN & Issue 4 \\
EAST-ASIAN & December 2014 \\
AFFAIRS & \\
\hline THE CHINA MONITOR \\
\hline
\end{tabular}

Xinlang Weibo. [Online]. Available: http://s.weibo.com/weibo/\%25E8\%258B\% $258 \mathrm{~F} \% 25 \mathrm{E} 4 \% 25 \mathrm{~B} 8 \% 25 \mathrm{~B} 9 \% 25 \mathrm{E} 4 \% 25 \mathrm{BA} \% 25 \mathrm{BA} \% 25 \mathrm{E} 8 \% 25 \mathrm{~B} 4 \% 25 \mathrm{~A} 8 \%$ 25E4\%25BA $\% 258 \mathrm{~B} \% 25 \mathrm{E} 4 \% 25 \mathrm{BB} \% 25 \mathrm{~B} 6 \&$ Refer=STopic_box [9 November 2013].

Yates, Douglas. 2012. The Scramble for African Oil: Oppression, Corruption and War for Control of Africa's Natural Resources, London: Pluto Press. 
